\author{
Małgorzata Ambrozik \\ Uniwersytet Łódzki \\ Instytut Geografii Miast i Turyzmu \\ Zakład Geografii Hotelarstwa \\ malgorzata.ambrozik@geo.uni.lodz.pl
}

\title{
PROBLEMATYKA ZAKWATEROWANIA TURYSTYCZNEGO W CZASOPIŚMIE „SCANDINAVIAN JOURNAL OF HOSPITALITY AND TOURISM”
}

\begin{abstract}
Abstrakt: Celem artykułu jest analiza treści publikowanych na łamach czasopisma naukowego „Scandinavian Journal of Hospitality and Tourism", ze szczególnym uwzględnieniem opracowań dotyczących szeroko rozumianego zakwaterowania turystycznego. Materiały źródłowe zostały zebrane podczas kwerendy w bazie Taylor \& Francis Online¹, w której są umieszczane kolejne internetowe wydania czasopisma.
\end{abstract}

Słowa kluczowe: zakwaterowanie turystyczne, branża turystyczna, Skandynawia.

\section{OGÓLNA CHARAKTERYSTYKA CZASOPISMA}

"Scandinavian Journal of Hospitality and Tourism" (SJHT) jest relatywnie nowym czasopismem (wydawanym od 2001 r.), które ma na celu inicjowanie i stymulowanie dyskusji dotyczącej zagadnienia gościnności i turystyki wśród menadżerów i decydentów akademickich zarówno w sektorze prywatnym, jak i publicznym, co z kolei ma wpływać na rozwój turystyki i hotelarstwa. Jest to wydawnictwo interdyscyplinarne, na łamach którego podejmowane są rozważania dotyczące geografii, ekonomii, psychologii, socjologii, historii czy antropologii. Czasopismo publikuje zarówno wszystkie rodzaje badań empirycznych opartych na różnorodnych metodach (ilościowych i jakościowych), jak i koncepcyjne kwestie dotyczące turystyki w Skandynawii, regionach Morza Północnego i Bałtyku, wraz z inwestycjami towarzyszącymi w lokalnej i regionalnej branży turystycznej. Wydawnictwo oprócz artykułów naukowych i recenzji książek przyjmuje głosy debatujących lub komentarze zagadnień będących przedmiotem zainteresowania badaczy i społeczności zawodowej (np. wydarzenia turystyczne, polityka badawcza, tematy filozoficzne związane $z$ branżą turystyczną itp.). SJHT wydawany jest $w$ ję- zyku angielskim, a wszystkim, którzy mogą potrzebować pomocy przy tłumaczeniu artykułów, udzielane jest wsparcie techniczne. Obecnie publikowany jest przez wydawnictwo Routledge $w$ formie kwartalnika.

Czasopismo stwarza autorom możliwość wydawania $w$ tzw. otwartym dostępie za pośrednictwem witryny internetowej Taylor \& Francis Group, w której artykuły są udostępniane natychmiast po ich ogłoszeniu. Wydawnictwo oferuje różne typy licencji, aby chronić prawa autorów zgłaszających swoje prace. W przypadku otwartego dostępu jest to m.in. licencja Creative Commons.

Głównym celem niniejszego opracowania było przygotowanie przeglądu artykułów, które ukazały się $\mathrm{w}$ czasopiśmie, a nawiązujących do podjętego przez autorkę tematu rozprawy doktorskiej, która najogólniej dotyczy bazy noclegowej. Sądząc po samym tytule SJHT powinno $\mathrm{w}$ dużej mierze publikować opracowania związane $\mathrm{z}$ tematyką zamierzonego doktoratu, które mogłyby być pomocne w przygotowaniu jego koncepcji. Sporządzając zestawienie artykułów z tego czasopisma autorka dążyła do opracowania bibliografii odnoszącej się do obiektów hotelarskich, 
która obejmowałaby różnorodne zagadnienia - począwszy od funkcjonowania samego obiektu i kadry w nim pracującej, po stosowane teorie marketingowe. Decyzja o wyborze SJHT związana była z kilkoma czynnikami. Przede wszystkim czasopismo dotyka interesującej autorkę tematyki bazy noclegowej z różnych punktów widzenia, co pozwala na uzyskanie kompleksowego obrazu zagadnienia. Dodatkowo znajduje się na liście filadelfijskiej, czyli należy do grona prestiżowych wydawnictw naukowych, w których publikują wybitni w swoich dziedzinach badacze, i terytorialnie związane jest ze Skandynawią i Europą Środkową.

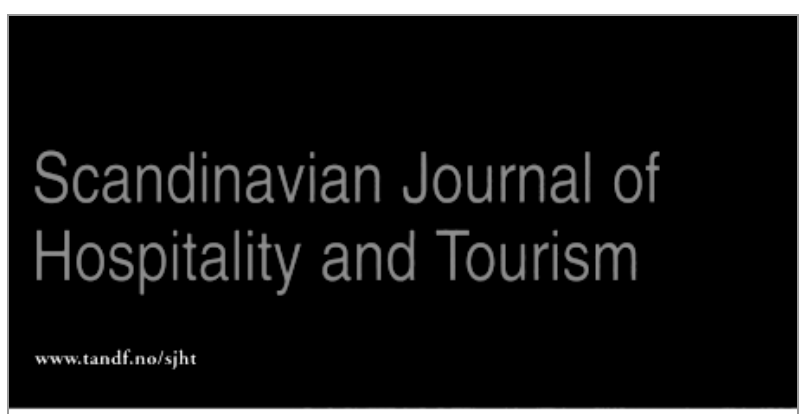

Volume $5 \cdot$ Number $2 \cdot 2005$

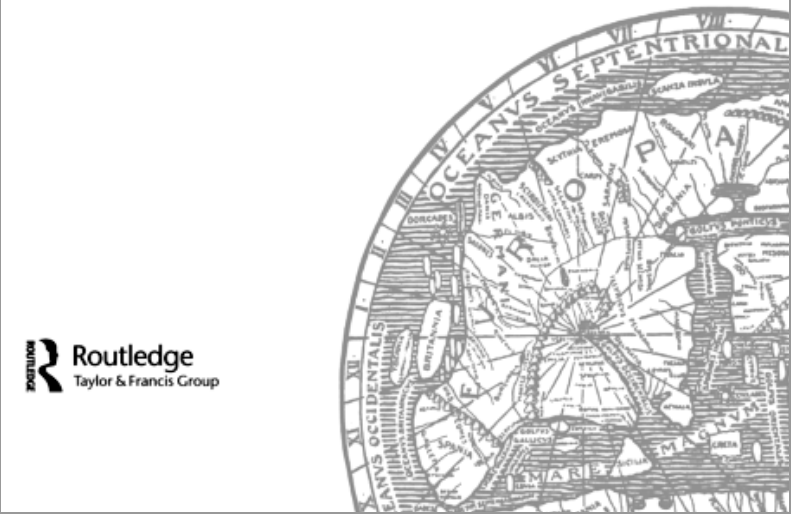

Rys. 1. Okładka czasopisma

"Scandinavian Journal of Hospitality and Tourism" Źródło: http:/ / explore.tandfonline.com/cfp/pgas/sjht/ guided-tours

\section{WSKAŹNIKI BIBLIOMETRYCZNE CZASOPISMA SJHT}

Czasopismo "Scandinavian Journal of Hospitality and Tourism" znajduje się na tzw. liście filadelfijskiej, tj. wykazie serii naukowych indeksowanych przez Institute of Scientific Information (ISI) w Filadelfii. Wskaźnik impact factor (IF), czyli wskaźnik prestiżu czasopi- sma naukowego, w 2016 r. dla tego periodyku wynosił 0,518² (0,882 w 2013 r. $\left.{ }^{3}\right)$. SJHT w roku 2013 było oceniane zarówno w kategorii "hospitality, leisure, sport and tourism”, jak i kategorii "sociology". Ponadto jest włączone do Thomson Reuters Social Sciences Citation Index - bazy danych artykułów, naukowców, analizy trendów. Warto również wspomnieć o innych bazach, w których czasopismo jest indeksowane. Są to: CABI (CAB Abstracts, Leisure Tourism Database, Nutrition and Food Sciences Database, Veterinary Science Database), CSA (CSA Human Population \& Natural Resource Management), CSA (Sustainability Science Abstracts, Environmental Sciences and Pollution Management), EBSCO host (Associates Program Source Plus, Business Source Alumni Edition, Business Source Complete, Business Source Corporate, Business Source Premier, Current Abstracts, Hospitality \& Tourism Complete, Hospitality \& Tourism Index, TOC Premier, Vocational Studies Complete), GEOBASE, Forestry Abstracts, Leisure, Recreation and Tourism Abstracts, OCLC (ArticleFirst, Electronic Collections Online, Environmental Sciences and Pollution Management), Plant Genetic Resources Abstracts, Scopus, Social Sciences Citation Index, World Agricultural Economics and Rural Sociology Abstracts.

Aktualnie czasopismo ma dwóch redaktorów naukowych. Są nimi Trude Furunes z Norwegian School of Hotel Management Uniwersytetu w Stavanger w Norwegii oraz Jens Kristian Steen Jacobsen z Uniwersytetu w Stavanger w Norwegii. W skład rady redakcyjnej czasopisma wchodzą: Tommy Andersson - Uniwersytet w Göteborgu w Szwecji, Peter Björk - Swedish School of Economics and Business Administration w Helsinkach w Finlandii, Adriana Budeanu - Copenhagen Business School w Danii, Peter Fredman - Mid-Sweden University, ETOUR w Szwecji, Gudrun Helgadottir - Holar University College w Islandii, Lena Mossberg - Uniwersytet w Göteborgu w Szwecji, Liisa Tyrväinen - Natural Resources Institute Finland w Helsinkach w Finlandii. Recenzją naukową zajmuje się Szilvia Gyimothy związana z Aalborg University w Danii. Siedziba czasopisma znajduje się w mieście Stavanger w Norwegii i jest związana z Norwegian School of Hotel Management oraz Uniwersytetem w Stavanger. Artykuły są publikowane na łamach czasopisma po uzyskaniu pozytywnych recenzji. Na recenzentów wybieranych jest zawsze minimum dwóch naukowców na podstawie ich zainteresowań i dorobku naukowego. Redakcja naukowa czasopisma stosuje zasadę double blind review, zgodnie z którą recenzent i autor nie znają swoich tożsamości.

Problematykę badawczą zamieszczaną w czasopiśmie SJHT można zaklasyfikować co najmniej do kilku grup, wśród których podejmuje się różnorodne tematy. 


\section{PROBLEMATYKA ZAKWATEROWANIA TURYSTYCZNEGO W PROFILU OGÓLNYM CZASOPISMA}

Typowy artykuł publikowany na łamach "Scandinavian Journal of Hospitality and Tourism" nie przekracza 7000 słów, w tej objętości znajdują się odniesienia oraz przypisy dolne i końcowe. Poza tym limitem znajdują się tabele oraz podpisy pod rysunkami. Biorąc pod uwagę tematykę czasopisma można podzielić ją na kilka głównych grup. Są to: rozwój zagospodarowania turystycznego, człowiek - konsument usług turystycznych, turystyka kulturowa i festiwale, tereny turystyczne (walory i atrakcje), podmioty oferujące usługi turystyczne, aktywność turystyczno-rekreacyjna różnych grup społecznych, zmiany klimatyczne a turystyka, turystyka na terenach niebezpiecznych.

W pierwszym bloku artykułów dotyczących rozwoju zagospodarowania turystycznego można wydzielić kilka podgrup traktujących o tym samym zagadnieniu, ale $z$ różnych perspektyw. Możemy tu wyróżnić m.in. „Rozwój turystyki i jej percepcję” z artykułami: The Right of Public Access - Opportunity or Obstacle for Nature Tourism in Sweden?; Differences in Tourists' and Local Residents' Perceptions of Tourism Landscapes: A Case Study from Ylläs, Finnish Lapland; EU and Tourism Development: Bark or Bite?; Branding Europe - Between Nations, Regions and Continents (tab. 1). Publikacje $\mathrm{w}$ tej podgrupie dotyczą teoretycznych rozważań związanych z rozwojem turystyki, globalizacji oraz zjawiska marki w turystyce. W przypadku globalizacji autorzy artykułów starają się odpowiedzieć na pytanie: $w$ jaki sposób chronić autentyzm miejsc i wydarzeń przed zbytnim uproszczeniem i niezrozumieniem ze strony turystów?

W podgrupie „Rozwój firm sektora branży turystycznej" znajdziemy np.: Tourism Employment and Creative In-migrants; Employer Size and Wages in the Hotel Industry; Obstacles to Developing Recreational Fishing Enterprises in Sweden; Work-Family Conflicts and Enrichment in the Norwegian Hotel Industry. W tej podgrupie umieścimy artykuły skupiające się na podmiotach prowadzących działalność związaną z organizowaniem turystyki i zakwaterowania. Część z publikacji podejmuje temat zatrudniania $\mathrm{w}$ sektorze turystycznym imigrantów ze szczególnym uwzględnieniem korzyści, jakie może to generować. Inne artykuły skupiają się nad rodzinnym prowadzeniem obiektu noclegowego i przedstawiają to zagadnienie na podstawie studium przypadku.

W podgrupie "Drugie domy" wymienimy np.: A New Approach to Spatial-Temporal Development of Second Homes: Case Study from Iceland; Second Home Ownership: A Blessing for All?; Local Residents' Valuation of Second Home Owners' Presence in a Sparsely Inhabited
Area; The Shift from Hotels and Lodges to Second-Home Villages in Mountain-Resort Accommodation. Artykuly wydawane $\mathrm{w}$ tej grupie można podsumować jako zestawienie wad i zalet dotyczących kupowania tzw. drugich domów i korzystania $\mathrm{z}$ nich.

Kolejnym dużym blokiem zagadnień poruszanych w publikowanych artykułach jest człowiek jako konsument usług turystycznych. Oczywiście w tej grupie również wydzielono pewne podgrupy skupiające się na konkretnych cechach konsumenta usług turystycznych. Możemy mówić w tym przypadku o „intencjach i motywacjach konsumentów". Wśród artykułów znajdziemy: The Role of the Body and Body Ideals in the Production and Consumption of Spa Experiences; Motives for Russian Second Home Ownership in Finland; Changes in Visitor Demand: Inter-year Comparisons of Swedish Hikers' Characteristics, Preferences and Experiences; Why Do People Purchase Nature-Based Tourism Activity Products? A Norwegian Case Study of Outdoor Recreation. Wybrane publikacje poruszają tematy związane $\mathrm{z}$ bodźcami, które stymulują ludzi do podejmowania różnych decyzji turystycznych oraz preferencji w wyborze konkretnej destynacji turystycznej. W dużej części są to artykuły powstałe na podstawie studium przypadku.

Odrębną podgrupą zagadnień jest „Satysfakcja klienta", gdzie zamieścimy m.in.: Family Flow: The Pleasures of "Being Together" in a Holiday Home; The Satisfaction of the Nordic Tourist with the Azores as a Destination; Environmentalism and Tourism Preferences: A Study of Outdoor Recreationists in Sweden. Artykuły skupiają się przede wszystkim na zadowoleniu klientów (turystów) oraz na analizie czynników, które mogą wpływać na poziom ich satysfakcji.

Ostatnią podgrupą zagadnień dotyczących konsumenta usług turystycznych jest „Emocjonalne doświadczenie turystyki" z artykułami: Between Risk and Comfort: Representations of Adventure Tourism in Sweden and Switzerland; Tourism Experience Innovation Through Design; Innovation and Value Creation in Experience-based Tourism. Teksty z tej grupy podejmują rozważania na temat emocji towarzyszących uprawianiu turystyki, emocji, które czasami związane są z nietypowymi lub nawet niebezpiecznymi czynnościami.

Dużo miejsca poświęca się problematyce związanej $\mathrm{z}$ trendami turystycznymi, walorami miejsc i atrakcjami stanowiącymi magnes dla turystów. W tym przypadku możemy rozróżnić prace dotyczące: „przygody turystycznej opartej na naturze". W tej podgrupie tematycznej odnaleźć można m.in.: Norwegian Landscapes: An Assessment of the Aesthetical Visual Dimensions of Some Rural Destinations in Norway; Nordic Slow Adventure: Explorations in Time and Nature; Tourism Impacts and Local Communities in Estonian National Parks. W większości artykuły te dotyczą wykorzystywania piękna przyrody w celach turystycz- 
Tab. 1. Artykuły dotyczące bazy noclegowej w czasopiśmie „Scandinavian Journal of Hospitality and Tourism”

\begin{tabular}{|c|c|c|c|}
\hline Numer & Tytuł artykułu & $\begin{array}{l}\text { Zakwalifikowany } \\
\text { na podstawie }\end{array}$ & $\begin{array}{c}\text { Otwarty } \\
\text { dostęp }\end{array}$ \\
\hline [1] & [2] & [3] & [4] \\
\hline \multirow[t]{3}{*}{$\begin{array}{l}\text { Vol. 15, issue 1-2, } \\
2015\end{array}$} & $\begin{array}{l}\text { Strategies in Norwegian Farm Tourism: Product Development, Challenges, } \\
\text { and Solutions }\end{array}$ & Treści abstraktu & Nie \\
\hline & Performing Gender and Rurality in Swedish Farm Tourism & Treści abstraktu & Nie \\
\hline & $\begin{array}{l}\text { Exploring Heterogeneous Tourism Development Paths: Cascade Effect or Co- } \\
\text { evolution in Niagara? }\end{array}$ & Treści abstraktu & Nie \\
\hline $\begin{array}{l}\text { Vol. 13, Supplement } \\
1,2014\end{array}$ & $\begin{array}{l}\text { The On-going Process of Reinventing Classic Tourism Destinations - The Case } \\
\text { of Nordic Tourists in Madeira Island }\end{array}$ & Słów kluczowych & Nie \\
\hline \multirow[t]{2}{*}{ Vol. 14, issue 3, 2014} & Green Meetings - Do They Matter to their Closest Stakeholders? & Słów kluczowych & Tak \\
\hline & The Use of Web 2.0 as a Marketing Tool by European Convention Bureaux & Tytułu & Nie \\
\hline \multirow[t]{3}{*}{ Vol. 14, issue 2, 2014} & Embodying the Rural Idyll in Farm Tourist Hosting & Tytułu & Nie \\
\hline & $\begin{array}{l}\text { Development of SERVQUAL and DINESERV for Measuring Meal } \\
\text { Experiences in Eating Establishments }\end{array}$ & Treści abstraktu & Nie \\
\hline & $\begin{array}{l}\text { Wise Emotion Regulation and the Power of Resilience in Experienced } \\
\text { Hospitality Leaders }\end{array}$ & Tytułu & Nie \\
\hline \multirow[t]{5}{*}{ Vol. 13, issue 4, 2013} & Second Home Ownership: A Blessing for All? & Tytułu & Nie \\
\hline & Motives for Russian Second Home Ownership in Finland & Tytułu & Nie \\
\hline & $\begin{array}{l}\text { Local Residents' Valuation of Second Home Owners' Presence in a Sparsely } \\
\text { Inhabited Area }\end{array}$ & Tytułu & Nie \\
\hline & $\begin{array}{l}\text { The Shift from Hotels and Lodges to Second-Home Villages in Mountain- } \\
\text { Resort Accommodation }\end{array}$ & Tytułu & Nie \\
\hline & Second Homes: Curse or Blessing? A Review 36 Years Later & Tytułu & Tak \\
\hline \multirow[t]{4}{*}{ Vol. 13, issue 3, 2013} & $\begin{array}{l}\text { The Role of the Body and Body Ideals in the Production and Consumption of } \\
\text { Spa Experiences }\end{array}$ & Tytułu & Nie \\
\hline & Family Flow: The Pleasures of "Being Together" in a Holiday Home & Treści abstraktu & Nie \\
\hline & $\begin{array}{l}\text { Contrasting Performances of Tourist and Migrant Mobilities in Norwegian } \\
\text { Hostels }\end{array}$ & Tytułu & Nie \\
\hline & $\begin{array}{l}\text { Landowners' Perception of Risk Sources and Risk Management Strategies in } \\
\text { Norwegian Salmon Angling Tourism }\end{array}$ & Treści abstraktu & Nie \\
\hline Vol. 13, issue 1, 2013 & $\begin{array}{l}\text { A New Approach to Spatial-Temporal Development of Second Homes: Case } \\
\text { Study from Iceland }\end{array}$ & Tytułu & Nie \\
\hline Vol. 12, issue 4, 2012 & Strategic Entrepreneurship in the Hotel Industry: The Role of Chain Affiliation & Tytułu & Nie \\
\hline Vol. 12, issue 3, 2012 & Employer Size and Wages in the Hotel Industry & Tytułu & Nie \\
\hline \multirow[t]{2}{*}{ Vol. 11, issue 4, 2011} & $\begin{array}{l}\text { Apprentices' Expectations and Experiences in the Socialisation Process in their } \\
\text { Meeting with the Hospitality Industry }\end{array}$ & Tytułu & Nie \\
\hline & Work-Family Conflicts and Enrichment in the Norwegian Hotel Industry & Tytułu & Nie \\
\hline \multirow[t]{2}{*}{ Vol. 11, issue 1, 2011} & Critical Service Encounters in Hotel Restaurants: The Personnel's Perspective & Tytułu & Nie \\
\hline & $\begin{array}{l}\text { Developing Wellness in Iceland. Theming Wellness Destinations the Nordic } \\
\text { Way }\end{array}$ & Tytułu & Nie \\
\hline Vol. 10, issue 1, 2010 & Visitors to Farm Tourism Enterprises in Norway & Treści abstraktu & Nie \\
\hline Vol. 9, issue 4, 2009 & $\begin{array}{l}\text { From "Home" to "Second Home": Emotional Dilemmas on Norwegian } \\
\text { Smallholdings }\end{array}$ & Tytułu & Nie \\
\hline \multirow[t]{2}{*}{ Vol. 9, issue 1, 2009} & A Grid Cell Viewopoint to Resorts: Case Studies in Northern Finland & Tytułu & Nie \\
\hline & $\begin{array}{l}\text { Silenced and Invisible: The Work-expirience of Room-attendants in Norvegian } \\
\text { Hotels }\end{array}$ & Tytułu & Nie \\
\hline \multirow[t]{2}{*}{ Vol. 8, issue 4, 2008} & $\begin{array}{l}\text { Corporate Social Responsibility in Hospitality: issues and Implications. A Case } \\
\text { Study of Scandic }\end{array}$ & Tytułu & Nie \\
\hline & $\begin{array}{l}\text { Why should Hospitality Management Focus more on the Construct of Basic } \\
\text { Assumptions? A Review and Research Agenda }\end{array}$ & Tytułu & Nie \\
\hline \multirow[t]{4}{*}{ Vol. 8, issue 3, 2008} & Extraordinary Experiences through Storytelling & Słów kluczowych & Nie \\
\hline & Exploring the Strategic Ground for Listening and Organizational Effectiveness & Słów kluczowych & Nie \\
\hline & $\begin{array}{l}\text { Competitive Dynamics and Pricing Behavior in US Hotels: The Role of Co- } \\
\text { location }\end{array}$ & Tytułu & Nie \\
\hline & Pricing Strategies in the Restaurant Industry & Tytułu & Nie \\
\hline Vol. 8, issue 1, 2008 & $\begin{array}{l}\text { Foreseeing the Future of Second Home Tourism. The Case of Finnish Media } \\
\text { and Policy Discourse }\end{array}$ & Tytułu & Nie \\
\hline Vol. 7, issue 4, 2007 & Hospitality Employees' Unemployment Risk: Panel Evidence from Norway & Tytułu & Nie \\
\hline
\end{tabular}




\begin{tabular}{|c|c|c|c|}
\hline [1] & [2] & [3] & [4] \\
\hline \multirow[t]{5}{*}{ Vol. 7, issue 3, 2007} & $\begin{array}{l}\text { The Development of Second Homes' Assessed Property Values in Sweden 1991- } \\
2001\end{array}$ & Tytułu & $\mathrm{Nie}$ \\
\hline & Recreational Home Users - Potential Clients for Countryside Tourism? & Słów kluczowych & Nie \\
\hline & $\begin{array}{l}\text { Environmental Impacts of Rural Second Home Tourism - Case Lake District in } \\
\text { Finland }\end{array}$ & Tytułu & $\mathrm{Nie}$ \\
\hline & Norwegian Cabin Life in Transition & Słów kluczowych & Nie \\
\hline & Settled Tourists: Second Homes as a Part of Tourist Life Stories & Tytułu & $\mathrm{Nie}$ \\
\hline Vol. 7, issue 2, 2007 & Price Differences at European Restaurants and Possible Implications for Tourism & Tytułu & Nie \\
\hline Vol. 6, issue 4, 2006 & Atmosphere: Conceptual issues and Implications for Hospitality Management & Tytułu & Nie \\
\hline Vol. 6, issue 3, 2006 & $\begin{array}{l}\text { Measuring the Relative Importance of Service Dimensions in the Formation of } \\
\text { Price Satisfaction and Service Satisfaction: A Case Study in the Hotel Industry }\end{array}$ & Tytułu & Nie \\
\hline Vol. 5, issue 3, 2005 & Training Paradox in the Hotel Industry & Tytułu & $\mathrm{Nie}$ \\
\hline \multirow[t]{2}{*}{ Vol. 5, issue 2, 2005} & Age Management in Norwegian Hospitality Businesses & Tytułu & Nie \\
\hline & The Meal Experiences of a la Carte Restaurant Customers & Tytułu & Nie \\
\hline Vol. 5, issue 1, 2005 & Family Holidays. A Qualitative Analysis of Family Holiday Experiences & Treści abstraktu & Nie \\
\hline \multirow[t]{2}{*}{ Vol. 4, issue 3, 2004} & $\begin{array}{l}\text { Quantitative or Qualitative? A Content Analysis of Nordic Research in Tourism } \\
\text { and Hospitality }\end{array}$ & Tytułu & $\mathrm{Nie}$ \\
\hline & Advancement in Computing: Implications for Tourism and Hospitality & Tytułu & $\mathrm{Nie}$ \\
\hline Vol. 4, issue 2, 2004 & $\begin{array}{l}\text { Implementing Quality and Health/Safety Systems in the Hospitality Industry. A } \\
\text { Comparison with the Aluminium Industry in Norway }\end{array}$ & Tytułu & Nie \\
\hline \multirow[t]{2}{*}{ Vol. 2, issue 2, 2002} & Development of Second-Home Tourism in Denmark & Tytułu & Nie \\
\hline & $\begin{array}{l}\text { Merging Systematic Occupational Health and Safety Management with Food } \\
\text { Control: A Healthy Recipe for the Hospitality Industry }\end{array}$ & Tytułu & Nie \\
\hline \multirow[t]{2}{*}{ Vol 2, issue 1, 2002} & Farm Tourism in Sweden: Structure, Growth and Characteristics & Treści abstraktu & $\mathrm{Nie}$ \\
\hline & Hotels as Learning Arenas & Tytułu & Nie \\
\hline
\end{tabular}

Źródło: opracowanie własne na podstawie strony internetowej http://www.tandfonline.com.taylor-francis.han3.lib.uni.lodz. $\mathrm{pl} / \mathrm{loi} / \mathrm{sjht} 20$.

nych, budowania produktów turystycznych opartych właśnie na naturze.

W podgrupie „Turystyka wiejska” zamieścimy np.: Strategies in Norwegian Farm Tourism: Product Development, Challenges, and Solutions; Performing Gender and Rurality in Swedish Farm Tourism; Implications of Climate Change for Rural Tourism in the Nordic Region. Opracowania dotyczą zagadnień teoretycznych, sprawdzania teorii, budowania strategii marketingowych oraz wyników przeprowadzonych badań empirycznych.

Ostatnią podgrupą tematyczną jest „Turystyka na obszarach chronionych" i w niej artykuły: People, Places, Protected Areas and Tourism: Place Attachment in Rossport, Ontario, Canada; Harmony or Conflict? A Focus Group Study on Traditional Use and Tourism Development in and around Rondane and Jotunheimen National Parks in Norway; National Park Visitor Segments and their Interest in Rural Tourism Services and Intention to Revisit. Sac to prace $\mathrm{w}$ większości dotyczące ruchu turystycznego w parkach narodowych, wpływu wielkości ruchu turystycznego na miejsca podlegające ochronie czy odkrywania piękna przyrody.

Zagadnienie dotyczące podmiotów oferujących usługi turystyczne można podzielić ze względu na kwestie: „Wdrażanie innowacji w firmach”. W podgrupie tej można wyróżnić artykuły opisujące wykorzystanie najnowszych technologii (najczęściej telefonów komórkowych i Internetu) w polepszaniu jakości oferowanych usług turystycznych oraz przygotowywaniu nowych usług oferowanych turystom, np. ICT Innovation and Local Economy: Mobile Game as a Tourist Attraction; mGuiding (Mobile Guiding) - Using a Mobile GIS app for Guiding; Innovative Processes in a Nature-Based Tourism Case: The Role of a Tour-operator as the Driver of Innovation.

„Rozwój kadry w branży turystycznej” to podgrupa tematyczna, w której odnajdziemy takie prace, jak.: Tourists Co-producing Guided Tours; Walking-Based Arts: A Resource for the Guided Tour?; Looking for the Right Kind of Person: Recruitment in Nature Tourism Guiding. Zdecydowana większość artykułów skupia się na kompetencjach kadry pracującej w branży turystycznej. Kompetencjach, które powinny być stale podnoszone, aby wychodzić naprzeciw oczekiwaniom klientów oraz umożliwiających realizację założonych celów.

"Zarządzanie i strategie w branży turystycznej" to ostatnia podgrupa tematyczna opisująca podmioty branży turystycznej. Tematy publikacji skupiają się na wykorzystywaniu mediów społecznościowych w celu zwiększenia zainteresowania świadczonymi usługami lub wdrażania strategii marketingowych. Przykłady artykułów: Social Media Strategies and Destination Management; Competitive Dynamics and Pricing Behavior in US Hotels: The Role of Co-location; Pricing Strategies in the Restaurant Industry. 
Odrębną grupę stanowią artykuły dotyczące „aktywności turystyczno-rekreacyjnej różnych grup społecznych". Wśród nich można zamieścić m.in.: Contrasting Performances of Tourist and Migrant Mobilities in Norwegian Hostels; Seasonal Workers in Swedish and Norwegian Ski Resorts - Potential In-migrants?; The Nordic Tourists in the Atlantic Islands of Azores, Madeira and Canaries. Tematy tych publikacji skupiają się na analizie wyników badań aktywności turystycznej z uwzględnieniem statusu uczestnika badań (obywatel kraju lub imigrant), wskazują pewne zależności i porównują różne grupy społeczne ze sobą.

Publikowane na łamach SJHT artykuły poruszają również ważny aspekt "Zmian klimatycznych a turystyki", w tym np.: Arctic Tourism and Sustainable Adaptation: Community Perspectives to Vulnerability and Climate Change; Will Climate Change Kill Santa Claus? Climate Change and High-Latitude Christmas Place Branding; Tourism and the Anthropocene. To tylko kilka przykładów podejmowanych w ramach tego bloku tematycznego. Można zauważyć m.in. zainteresowanie zrównoważonym rozwojem sektora turystycznego jako remedium na zachodzące zmiany klimatyczne i zaniepokojenie zmianami, które mogą osłabić lub zrujnować pewne tereny turystyczne.

"Turystyka na terenach niebezpiecznych" to grupa artykułów dotyczących niebezpieczeństwa na obszarach atrakcyjnych turystycznie wywołanego zarówno przez siły przyrody, jak i działanie człowieka. Przykładowe artykuły, to: Effects of Sudden and Dramatic Events on Travel Desire and Risk Judgments; Development of a Mechanism for Typhoon- and Flood-risk Assessment and Disaster Management in the Hotel Industry - A Case Study of the Hualien Area; Proactive Crisis Planning: Lessons for the Accommodation Industry.

Ostatnią dużą grupą tematyczną jest „Turystyka kulturowa, festiwale” reprezentowana przez takie pra- ce, jak: Impacts of Cultural Events in Eastern Finland - Development of a Finnish Event Evaluation Tool; Exploring the Success of the Gladmatfestival (The Stavanger Food Festival); Festival Ownership. Differences between Public, Nonprofit and Private Festivals in Sweden. Artykuły te skupiają się na analizach poszczególnych festiwali jako wydarzeń stanowiących atrakcję dla turystów oraz sprawdzają różnice między różnymi formami organizowania takich przedsięwzięć.

\section{PROFIL BRANŻOWY A PROFIL OGÓLNY - PODOBIEŃSTWA I RÓŻNICE}

Z wszystkich dostępnych na stronie internetowej artykułów do grupy dotyczącej szeroko rozumianego zakwaterowania turystycznego zakwalifikowano 57 artykułów z 29 tomów. Może się wydawać, że jest to dobry wynik, ale zważywszy, że wszystkich opublikowanych artykułów włącznie z 2015 r. było 269 (w 52 tomach), to już samo zestawienie tych dwóch wartości pokazuje, że tematyka związana $\mathrm{z}$ bazą noclegową stanowi jedynie mały fragment podejmowanych rozważań.

Dodatkowo pojawia się problem dotyczący kwalifikowania poszczególnych artykułów do grupy dotyczącej zakwaterowania turystycznego. Sytuację tę można rozwiązać na trzy sposoby. Po pierwsze można kierować się hasłem związanym z zakwaterowaniem w tytule artykułu, np. Hotels as Learning Arenas (vol. 2, no. 1, 2002), czy Age Management in Norwegian Hospitality Businesses (vol. 5, no. 2, 2005). Drugim sposobem jest kierowanie się słowami kluczowymi, wśród których znajdują się dotyczące bazy noclegowej, np. w słowach kluczowych dla artykułu pt. Recreational Home Users - Potential Clients for Countryside Tourism?

Tab. 2. Wydania specjalne czasopisma „Scandinavian Journal of Hospitality and Tourism”

\begin{tabular}{|l|l|c|c|}
\hline \multicolumn{1}{|c|}{ Numer tomu } & \multicolumn{1}{|c|}{ Tytuł wydania specjalnego SJHT } & $\begin{array}{c}\text { Liczba } \\
\text { artykułów }\end{array}$ & $\begin{array}{c}\text { Otwarty } \\
\text { dostęp }\end{array}$ \\
\hline Vol. 12, issue 1, 2012 & Special issue: Guided Tours and Tourism & 5 & Nie \\
\hline Vol. 11, Supplement 1, 2011 & $\begin{array}{l}\text { Special issue: Tourism in Protected Natural Areas: The Nordic-Baltic } \\
\text { Context }\end{array}$ & 5 & Nie \\
\hline Vol. 11, issue 3, 2011 & $\begin{array}{l}\text { Special issue: Tourism in a Decade of Terrorism, Disasters and Threats - } \\
\text { Some Lessons Learned }\end{array}$ & 10 & Nie \\
\hline Vol. 9, issue 2-3, 2009 & Special issue: Festival Management & 11 & Nie \\
\hline Vol. 8, issue 3, 2008 & Special issue: Strategy in Hospitality Management & 4 & Nie \\
\hline Vol. 7, issue 3, 2007 & Special issue: Second Homes & 5 & Nie \\
\hline Vol. 7, issue 1, 2007 & Special issue: Tourist Experiences & 5 & Nie \\
\hline Vol. 6, issue 1, 2006 & Special issue: Tourism and the Sámi & 4 & Nie \\
\hline
\end{tabular}

Źródło: opracowanie własne na podstawie strony internetowej http:/ / www.tandfonline.com.taylor-francis.han3.lib.uni. lodz.pl/loi/sjht20. 
(vol. 7, no. 3, 2007) można odnaleźć termin „second home" (drugie domy). Ostatnia możliwość to próba odszukania haseł związanych z branżą w abstraktach artykułów, np. w pracy Extraordinary Experiences through Storytelling (vol. 8, no. 3, 2008) występuje słowo „hospitality" (gościnność).

Wspomniane powyżej 57 artykułów zostało wybranych przede wszystkim na podstawie treści abstraktów. Gdyby kierować się tylko tytułem, to 41 artykułów zawiera w swoim tytule pojęcie nawiązujacce do zakwaterowania turystycznego. Dodatkowo w kolejnych sześciu pracach znajdujemy „gościnność" wśród słów kluczowych. Pozostałe 10 artykułów zakwalifikowano do przeglądu literatury dotyczącej bazy noclegowej na podstawie treści abstraktów, w której pojawia się nawiązanie do tej tematyki.

Zdarza się, że poszczególne tomy są profilowane, tzn. że artykuły zawarte $\mathrm{w}$ takim tomie podejmują tę samą tematykę. Cały zeszyt poświęcony jednej tematyce jest zwykle publikowany $w$ ramach wydania specjalnego, tzw. special issue (tab. 2). Na 52 tomy wydane do końca 2015 r. osiem $\mathrm{z}$ nich było profilowanych (pierwszy z 2006, a ostatni z 2012 r.). Wśród tematyki poruszanej $\mathrm{w}$ tych wydaniach specjalnych znaleźć można turystykę doświadczeń, turystykę określonych grup społecznych, turystykę kulturową, turystykę w dobie terroryzmu, turystykę na obszarach chronionych oraz przewodnictwo turystyczne. Zagadnienie zakwaterowania turystycznego zostało poruszone w dwóch zeszytach wydanych jako specjalne i dotyczyły drugich domów (2007 r. - 5 artykułów) oraz strategii w zarządzaniu gościnnością (2008 r. -4 prace).

\section{PROBLEMATYKA REGIONALNA CZASOPISMA}

Bardzo silnie zaznacza się regionalne oddziaływanie czasopisma. Już sama nazwa wskazuje, że obszarem badań i zainteresowań badawczych będą przede wszystkim tereny Skandynawii. Na stronie internetowej "Scandinavian Journal of Hospitality and Tourism" można znaleźć zagadnienia dotyczące basenów Morza Północnego i Bałtyckiego. Można więc wnioskować, że SJHT to tytuł hermetyczny jeśli chodzi o zasięg przestrzenny. Niemniej zdarzają się również artykuły dotyczące obszarów Ameryki Północnej, chociaż raczej incydentalnie. Autorzy publikowanych $\mathrm{w}$ nim prac pochodzą $\mathrm{z}$ różnych zakątków świata (choć przeważają naukowcy z Półwyspu Skandynawskiego), z różnych ośrodków akademickich. $\mathrm{Z}$ tego powodu treści poruszane na łamach czasopisma, nawet jeśli dotyczą w miarę homogenicznego obszaru badań, i tak są różnorodne.

\section{WNIOSKI KOŃCOWE}

"Scandinavian Journal of Hospitality and Tourism" jest czasopismem naukowym, w którym znajdujemy tematykę związaną z rozwojem i zmianami zachodzącymi w branży turystycznej na obszarze Skandynawii, u wybrzeży Morza Północnego i Morza Bałtyckiego. Chociaż wydawać by się mogło, że ograniczenie przestrzenne miejsc prowadzenia badań może być wadą lub przynajmniej przeszkodac, to należy pamiętać, że czasopismo korzysta $\mathrm{z}$ wiedzy i doświadczenia naukowców z całego świata, co pozwala spojrzeć na pewne zagadnienia $z$ różnych perspektyw, a także umożliwia dyskusję i wymianę poglądów. Różnorodna tematyka artykułów oraz stosowane metody analiz danych pozwalają czytelnikom śledzić na bieżąco trendy pojawiające się w sektorze turystycznym. Czasopismo porusza aktualne kwestie i problemy dotyczące turystyki jako nauki oraz prowadzonej działalności gospodarczej. Z całą pewnością jest to jedno z bardziej przydatnych wydawnictw zajmujących się branżą turystyczną, dostępne na rynku, nawet jeśli treści dotyczące samego zagadnienia gościnności są marginalnie poruszane na jego łamach. W pewnym stopniu autorce udało się zrealizować postawiony cel i przygotować przegląd artykułów związanych tematycznie z bazą hotelarska, niemniej jednak autorka nie jest usatysfakcjonowana przygotowanym opracowaniem. Istotny problem stanowi brak otwartego dostępu do pełnych artykułów. Opieranie się jedynie na abstraktach nie wystarczy, aby móc wyrobić sobie zdanie na interesujące tematy, może jedynie wskazać kierunek dalszych poszukiwań. Niniejszy artykuł jest jednak krokiem naprzód w gromadzeniu literatury wyjaśniającej zagadnienie bazy noclegowej.

\section{PRZYPISY}

${ }^{1} \mathrm{http}: / /$ www.tandfonline.com/.

${ }^{2} \mathrm{http}$ / / explore.tandfonline.com/page/bes/impactfactors $/$ slt.

${ }^{3} \mathrm{http}: / /$ www.tandfonline.com/action/journalInformation? journalCode $=$ sjht20.

\section{STRONY INTERNETOWE}

http://explore.tandfonline.com/cfp/pgas/sjht/guided-tours. http://explore.tandfonline.com/page/bes/impact-factors/slt. http://www.tandfonline.com/.

http://www.tandfonline.com.taylor-francis.han3.lib.uni.lodz.pl /loi/sjht20.

http://www.tandfonline.com/action/journalInformation?jour nalCode $=$ sjht 20 .

Artykuł wpłynął do redakcji: 10 listopada $2016 \mathrm{r}$.

Zaakceptowano do druku: 4 grudnia 2016 r. 